Laurie M. Bridges, Kelly McElroy:

\title{
Access to Information is (Not) a Universal Right in Higher Education: Li- brarian Ethics and Advocacy
}

\begin{abstract}
:
As a profession, librarians have proclaimed an ethical duty to ensure access to information for all people. However, many barriers exist to fulfilling this duty, including varying levels of education and technology around the globe, the cost of obtaining research information, and the concentration of scholarly publishing in English. This article outlines these barriers, concluding with a call to action for librarians to advocate for multilingual Open Access, to foster international scholarly communities, and to champion Internet access for all.

简介：作为一个行业，图书馆员一直将所有人能够接入信息当作道德责任。但是，存在很多障碍，包括全球不 同教育与技术层次，取得科研信息的费用，以及论文出版集中使用英语。本论文列出这些障碍，总结图书馆员 应支持多语种开放接入，国际学术交流，以及主导所有人接入互联网。

A nivel profesional los bibliotecarios han proclamado un responsabilidad ética que asegure acceso a la información a la población entera. Aún así existen muchas barreras para cumplir este cometido, entre ellos distintos niveles educativos y tecnológicos alrededor del planeta, costes a la hora de obtener información de investigación y concentración de publicaciones académicas en inglés. Éste artículo da una idea general de cuáles son estas barreras, concluyendo con un llamamiento a los bibliotecarios a actuar promocionando un Acceso Abierto multilingüe, impulsando comunidades académicas internacionales y abogando por el acceso a Internet para todo el mundo.
\end{abstract}

\section{Agenda:}

Introduction

Barriers: Sixteen Countries Compared

Educational Attainment and Internet Access

Language

The Costs of Access to Information in Higher Education 40

The business of publishing.

Language in scholarly publishing 41

Conclusion and Recommendations

Advocate for Open Access 42

Advocate for Multi-Lingual Open Access...... 42

Foster an International Scholarly Community 43

Advocate for Internet Access for All 


\section{Authors:}

Laurie M. Bridges:

- Associate Professor and Instruction \& Outreach Librarian, Oregon State University

- $\quad$ 留 1 (541) 737-8821, $\square$ laurie.bridges@oregonstate.edu, 묘osulibrary.oregonstate.edu/staff/bridges|

Kelly McElroy:

- Assistant Professor, Student Engagement \& Community Outreach Librarian, Oregon State University

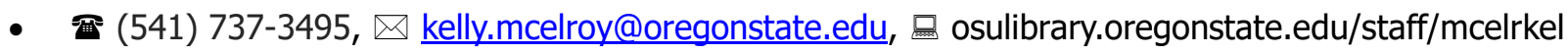




\section{Introduction}

It is estimated there are over 600,000 librarians worldwide. ${ }^{1}$ More than sixty national library associations have a code of ethics in place to inform how librarians work toward providing access to information for their patrons. As recently as 2012 the leading international body that represents librarians and their interests, the International Federation of Library Associations and Institutions (IFLA), approved the IFLA Code of Ethics for Librarians and Other Information Workers. ${ }^{2}$ This document contains a preamble, which is described as core principles, followed by six clauses that are used to "provide a set of suggestions on the conduct of professionals." We, two academic librarians in the United States, are primarily interested in the universality and applicability of the first four sentences of the first clause titled, "Access to information":

The core mission of librarians and other information workers is to ensure access to information for all for personal development, education, cultural enrichment, leisure, economic activity and informed participation in and enhancement of democracy. Librarians and other information workers reject the denial and restriction of access to information and ideas most particularly through censorship whether by states, governments, or religious or civil society institutions. Librarians and other information workers offering services to the public should make every endeavour to offer access to their collections and services free of cost to the user. If membership fees and administrative charges are inevitable, they should be kept as low as possible, and practical solutions found so that socially disadvantaged people are not excluded.

In addition to this clause in the IFLA Code of Ethics, the United Nation's Universal Declaration of Human Rights Article 19 declares access to information is a fundamental human right. ${ }^{3}$ However, despite these statements, interlocking systems of financial and linguistic inequality have made it difficult for researchers to share their research globally.

Segmented access to information can have profound consequences. A recent New York Times editorial by Liberian health officials noted that the threat of Ebola had been identified as far back as 1982, but the research was locked in expensive journal archives inaccessible to health practitioners in that country. ${ }^{4}$ They note, "Had the virologists' findings been linked to long-term efforts to train Liberians to conduct research, to identify and stop epidemics, and to deliver quality medical care, the outcome might have been different." Where conversations about intellectual freedom in librarianship often focus on civil liberties and political freedoms, we wish to explore the new neocolonialism of scholarly publishing. ${ }^{5}$ We will examine the economic and linguistic barriers to international access of scholarly information, and place them in the context of the ethical responsibilities of librarians.

\section{Barriers: Sixteen Countries Compared}

This article aims to highlight the barriers scholars face in obtaining and sharing research across international borders in higher education; to that end, we have selected sixteen countries to provide a brief overview of some barriers. These comparisons are intended to shed light on the limitations faced by scholars in various countries, in order to encourage librarians to effectively advocate for all scholars and librarians, beyond their individual country's borders.

\footnotetext{
1 "Libraries: How They Stack up," 6.

2 "IFLA Code of Ethics for Librarians and Other Information Workers (Full Version)."

3 "United Nations Declaration of Human Rights."

${ }^{4}$ Dahn, Mussah, and Nutt, "Yes, We Were Warned about Ebola."
}

${ }^{5}$ Altbach, "Globalisation and the University: Myths and Realities in an Unequal World," 9. 
Although the country comparison is limited to sixteen in number, we believe it accomplishes our goal: elucidating the inequality between countries in regards to higher education and access to research information. We identified countries for comparison by turning to the IFLA advocacy group, Committee on Freedom of Access to Information and Freedom of Expression (FAIFE). The FAIFE committee is dedicated to protecting intellectual freedom and freedom of expression. ${ }^{6}$ In 2015 the committee was comprised of members from sixteen countries, and because membership in the FAIFE committee indicates some level of commitment by librarians in that country to freedom of access, we decided to use these countries for comparison: Germany, Switzerland, Côte d'Ivoire, France, UK, Serbia, Egypt, Zimbabwe, Japan, Finland, Mexico, Ukraine, Canada, Russia, and China. ${ }^{7}$ We also included our home country, the US.

\section{Educational Attainment and Internet Access}

The sixteen countries in our comparison (Figure 1) vary greatly in population size. At the highest end is China, with approximately 1.4 billion and at the low end is Finland with approximately 5.5 million. No matter what the population, access to information can be hampered by a lack of access to the Internet. Côte d'Ivoire has the lowest usage with only $2.4 \%$ of the population using the Internet, and the second lowest is Zimbabwe at $17.1 \%$. Another revealing number (Figure 1 ) is the percentage of the population, age 25 or over, who have a bachelor's degree or higher; Zimbabwe is the lowest at 2.4\% (UNESCO did not have this information for Côte d'Ivoire or Egypt). Also interesting is the low percentage of degree holders in China-out of 1.4 billion people only $3.6 \%$ hold a bachelor's degree or higher. Low degree attainment coupled with low Internet access begins to reveal some of the difficulties faced by scholars in resource-poor countries.

\footnotetext{
6 "Committee on Freedom of Access to Information and Freedom of Expression (FAIFE)."

7 "Members of the FAIFE Committee."
} 
Figure 1 - Percentage of population who are Internet users ${ }^{8}$; Percentage of population, 25 and over, with a bachelor's degree or higher ${ }^{9}$; Population projections for $2015^{10}$.

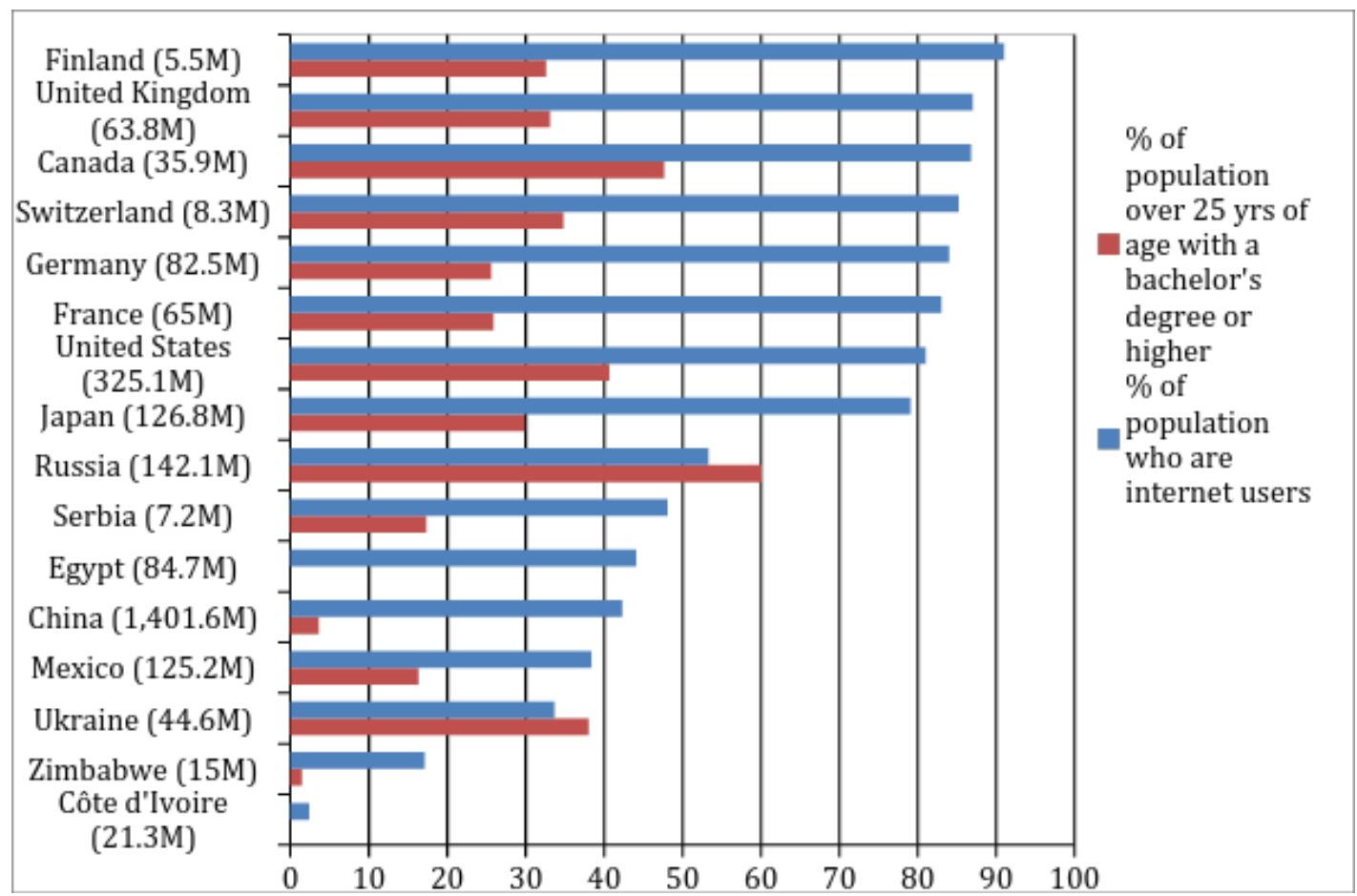

\section{Language}

There are over 7,000 living languages in the world, ${ }^{11}$ but despite this, two thirds of the world's population are native speakers of one of the following twelve languages (in descending order): Chinese, Hindi-Urdu, English, Arabic, Spanish, Bengali, Russian, Portuguese, German, Japanese, French, and Italian. ${ }^{12}$ Although Chinese and Hindi-Urdu have the largest number of native speakers, English is by far the world's most commonly studied foreign language, with 1.5 billion learners. ${ }^{13}$ In distant second place, with 82 million learners, is French. A recent 2015 report from the Pew Research Center noted that among 32 developing and emerging nations, people who read or spoke English were more likely to use the Internet, as were people with a secondary education or higher. ${ }^{14}$ English has undeniably become the de facto language used in international communication and not knowing English poses a significant barrier for scholars.

\footnotetext{
8 "Sustaining Human Progress: Reducing Vulnerabilities and Building Resilience."

9 "UNESCO Institute for Statistics Data Centre."

10 "World Population Prospects: The 2012 Revision."

11 "Ethnologue: Languages of the World."

${ }^{12}$ Ammon, Ulrich cited in Noack and Gamio, "The World's Languages, in 7 Maps and Charts."

${ }^{13}$ Ammon, Ulrich cited in ibid.

14 "Internet Seen as Positive Influence on Education but Negative on Morality in Emerging and Developing Nations."
} 


\section{The Costs of Access to Information in Higher Education}

Although the freedom to seek, receive, and impart information is recognized as a human right, that information is rarely free. Advocates of open source software often use the comparison that these tools are free like a puppy (requiring ongoing feeding and care) rather than a beer (which you can consume with no added expense). As previously discussed, the technological infrastructure and access to education contribute to the ability to access information of various types. In this section we will explore the explicit and hidden costs of access to scholarly journal articles, the dominant form used to share academic research. As Lawson, Sanders, and Smith have noted, when research information has an economic value, "access to such information [...] is not a right but a privilege. ${ }^{\prime 15}$ We will discuss global and regional trends surrounding the literal cost of access to scholarly publications, as well as linguistic barriers as researchers create and share information.

\section{The business of publishing}

Scholarly publishing is big business. As John Cox has noted, scholarly publishing is often funded by public/government money, and independently of the broader economy, making it a stable investment. ${ }^{16}$ Over the years, a series of mergers and acquisitions has concentrated where scholarly materials are published, ultimately creating an oligopolistic industry. In 2014, the world's ten largest book publishers were all based in the US or Europe. ${ }^{17}$ Six of them publish largely educational or scholarly material. Although some of these companies, such as Pearson, focus mostly on textbooks and testing materials, the portfolios of each publisher contains databases of research information. Examining just one provider, Reed Elsevier Group, reveals a striking pattern: $51 \%$ of their 2012 revenues came from North America, $28 \%$ from Europe, and $21 \%$ from all other countries combined. ${ }^{18}$ We see this pattern repeated across companies: Thomson Reuters saw $57 \%$ of their revenues coming from the US, and Wolters Kluwer $54 \% .{ }^{19}$ There are likely multiple explanations for the high percentage of revenues generated in the United States. Given the US population and rate of educational achievement noted previously (Figure 1), the academic publishing market is large. The cost of higher education in the United States is also notably high. National site licensing agreements have not caught on in the United States as they have in countries such as Canada and the United Kingdom, so vendors may have more leverage while dealing with individual institutions and small regional consortia in the US. ${ }^{20}$ Finally, when prices are set in wealthy countries like the United States, it can be prohibitively expensive for universities in developing countries. ${ }^{21}$

However, not all scholarly journals are published by for-profit publishers. An alternative model, Open Access (OA) publishing, shifts the costs to authors or other institutions to provide articles freely to readers online. Uptake has varied by discipline and region, although a 2011 study of articles indexed in Scopus found that $17 \%$ of articles published in that year were available OA through journal publishers. ${ }^{22}$ Individual authors can also deposit pre-print versions of articles in their own institutional repositories under arrangements with many publishers. Ibero-American cooperative efforts such as SciELO and Redalyc are frequently touted as OA suc-

\footnotetext{
${ }^{15}$ Lawson, Sanders, and Smith, "Commodification of the Information Profession," 12.

${ }^{16}$ Cox, "As I See It! -- Why Is Private Equity Interested In Publishing?," 69.

17 "The World's 56 Largest Book Publishers, 2014."

18 "Global Publishing Leaders 2014."

19 "Global Publishing Leaders 2014."

${ }^{20}$ Xiaohua Zhu, "The National Site Licensing of Electronic Resources."

${ }^{21}$ Altbach, "Globalisation and the University: Myths and Realities in an Unequal World," 11.

${ }^{22}$ Laakso and Björk, "Anatomy of Open Access Publishing."
} 
cess stories, boosting the visibility of scientific publishing in a region previously underrepresented in the scholarly record. ${ }^{23}$ However, OA still requires technological infrastructure and ongoing financial commitment on the part of the host institution and, of course, Internet access for the reader.

\section{Language in scholarly publishing}

As noted earlier, English is by far the most commonly studied language. The role of English as the international language of science and scholarship has also been well established. By 1998, over 95\% of the publications in the Science Citation Index were published in English. ${ }^{24}$ Although some scholars recognize the benefits of efficiency and the impact of the free market in this consolidation, others lament the homogenization and gatekeeping, noting, for example, that localized discourse patterns may be dismissed as non-standard by reviewers. ${ }^{25}$ The limitations of English-language domination have been noted in specific fields ranging from feminist theory to epidemiology. ${ }^{26}$

In terms of the human right to information access, this linguistic monopoly creates several barriers for scholars whose native language is not English. First, researchers who do not speak or write in English will find their options for giving presentations at conferences or publishing in academic journals severely limited; as an example, almost all scientific journals published in Germany are now in English, a trend that began in the 1970s. ${ }^{27}$ Non-native speakers may feel most comfortable as consumers, rather than producers, of scholarly material in English. ${ }^{28}$ Scholars who are proficient in English may feel pressure to publish in English-language journals because the resulting publication may be seen as more prestigious or higher-impact when compared to journals in their native language. ${ }^{29}$ As a final barrier, even minor errors may be held against a scholar, as native English-speaking reviewers and editors often view the writing of non-natives negatively. ${ }^{30}$

An inability to read English can also limit how a researcher locates and uses the published work of others. Although online tools such as Google Translate can help a researcher read a located item, the paywalled databases and indexes, if available, may only be searchable in some languages-for example the database World of Science only provides searching interfaces in Korean, Japanese, both simplified and traditional Chinese, Spanish, Portuguese, and English. The articles, of course, are not fully translated. This cycle then perpetuates itself, as English-language articles are more discoverable and more cited.

A few quick searches in Ulrichsweb, a database of periodical information that aims to be globally comprehensive, demonstrates the dominance of English-language journals. Limiting the search to active, academic/scholarly publications not published in English yields 52,498 results compared with 95,604 in English. Further limiting the results to peer-reviewed/refereed titles cuts these down to 12,965 and 59,573, respectively. (Of course, some of the primarily English-language titles may also welcome articles in some other languages. However, even a multilingual journal such as this one may have a concentration in one language: $85 \%$ of the full-length articles published in IRIE to date have been written in English.)

\footnotetext{
${ }^{23}$ Alperin, Fischman, and Willinsky, "Open access and scholarly publishing in Latin America," 177.

${ }^{24}$ Van Leeuwen et al., "Language Biases in the Coverage of the Science Citation Index and Its Consequences for International Comparisons of National Research Performance," 344.

25 Tardy, "The Role of English in Scientific Communication."

${ }^{26}$ Descarries, "Language Is Not Neutral"; Baussano et al., "Does Language Matter?"

27 Ammon, "Global English and the Non-Native Speaker: Overcoming Disadvantage."

28 Tardy, "The Role of English in Scientific Communication," 251.

${ }^{29}$ Fischman, Alperin, and Willinsky, "Visibility and Quality in Spanish-Language Latin American Scholarly Publishing," 13.

${ }^{30}$ Ammon, "Global English and the Non-Native Speaker: Overcoming Disadvantage."
} 
The dominance of English across international academia does not only affect researchers, but also the public. Research funded by the public in both resource-poor and -rich countries is likely to be published in English, thereby creating roadblocks for the public, if they do not read in English. ${ }^{31}$ For example, in the majority of countries in the sixteen countries compared in Figure 1, English is not the native or primary language; in Côte $\mathrm{d}^{\prime}$ Ivoire the official language is French, in Mexico it is Spanish, and in Serbia it is Serbian. Even when articles are Open Access, how can the public, including medical doctors, nurses, engineers, and teachers, take advantage of the knowledge shared when they do not read English?

\section{Conclusion and Recommendations}

Varying levels of education and technology, the expense of obtaining the majority of research articles, and a concentration of scholarly publishing in English makes it clear that equitable access to information is far from a global reality. How can librarians, committed to supporting the universal right to information, advocate for freedom of access in our daily work? We see several possibilities for academic librarians, such as ourselves, who work in the financially wealthy countries that dominate research and scholarly publishing.

\section{Advocate for Open Access}

Through collaborations like Electronic Information for Libraries (eifl.net), librarians bring together the strengths of over 60 countries in Europe, Asia, Europe, and Latin America to negotiate and enable access to corporate electronic journals for resource-poor countries. This is done by leveraging the buying power of resource-poor countries and by negotiating a multi-country consortium. However, corporate deals are not enough, especially when considering the ever-increasing costs of journals. Librarians in the US and other resource-rich countries have an ethical obligation to promote Open Access Initiatives within their own countries when considering how corporate control of academic publishing disenfranchises resource-poor countries from the research, publishing, and access cycle. We can advocate for a more equitable distribution of the research produced on our own campuses by encouraging faculty to publish in Open Access journals or to at least deposit their pre-print papers into our institutional repositories. We can also play a role in highlighting and promoting awareness of international and Open Access resources.

\section{Advocate for Multi-Lingual Open Access}

As stated previously, even when articles are Open Access, the fact that most articles are published in English poses a significant problem for scholars and the general public due to language inequality. Therefore, librarians should advocate for multi-lingual Open Access. In 2008, Isaac Fung, a scholar in epidemiology, published an article advocating for multi-lingual Open Access calling on "...scientists and journal editors working in the English-speaking world, given the vast resources we have at hand compared to our counterparts in the developing world, to facilitate the dissemination of scientific knowledge between North and South and between Anglophone peoples and non-Anglophone peoples." ${ }^{32}$ Although Fung only lists scientists and editors, we would also add librarians to the list of advocates. Fung has four suggestions for future advocacy in this area; 1) Translations of English abstracts (or entire articles) into other languages at the time of publication; 2) Wiki-type editing for open translations of abstracts or entire articles; 3) International board of translator-editors who willingly provide translations for abstracts or articles; and 4) Alternative language versions of journals.

\footnotetext{
${ }^{31}$ Fung, "Open Access for the Non-English Speaking World: Overcoming the Language Barrier."

${ }^{32}$ Ibid.
} 


\section{Foster an International Scholarly Community}

One of us is an English-language copyeditor for a multi-lingual Spanish journal, an experience that has offered an opportunity for cross-cultural sharing of professional knowledge. However, this type of service is also problematic: for example, the call for editors sought native English speakers, reinforcing the linguistic barriers discussed in this piece. However, despite the ethical quandary, many scholars around the globe have the desire to better their English skills for academic writing and publication.

A study conducted at the Universidad Nacional Autónoma de Méxco surveyed 257 instructors and researchers about their experience with multiple languages, including barriers, in scholarship. Although Spanish was found to be the most used language, English and French were also highly used followed by German, Italian, and Portuguese. García Landa found that faculty primarily used three methods to overcome their linguistic limitations: the most common solution was independent learning, followed by asking a third party, and the last solution was using a translation dictionary. She was surprised to find that participants did not take formal classes. As a scholar in teaching and languages, García Landa states these linguistic learning solutions point to "a transformation in the ways of teaching/learning a language in the academic realm. In this sense, the fact that academics turn to autonomous learning, third parties and dictionaries is indicative of the necessity of implementing communities of academic writing." ${ }^{33}$

As librarians, how can we support international scholars as they seek solutions to language limitations posed by international publications? At our university we have over 500 international scholars, some are permanent employees and others are visiting. There may be opportunities to provide workshops for visiting scholars related to publishing in US academic journals, conducting research, and working with the writing center on manuscripts. In addition, there may exist opportunities to host language conversation groups for faculty members. Finally, if faculty are learning languages independently, we can advertise free services such as Duolingo, Google Translate, make sure we have current bi-lingual dictionaries on hand, and advertise existing language learner services on campus.

\section{Advocate for Internet Access for All}

Today, access to information depends largely on access to the Internet, and as shown in Figure 1, Internet usage varies widely by country. Lack of Internet access is a barrier for scholars, especially those in resourcepoor countries. Even if scholars have Internet access, connections may be slow and cumbersome. Broadband Internet access is necessary to seek, receive, and impart information; in 2011 the United Nations Special Rapporteur presented a report to the United Nations Human Rights Council calling on all member States to provide universal access to the Internet. ${ }^{34}$ The Special Rapporteur indicated that without Internet access, "marginalized groups and developing States remain trapped in a disadvantaged situation, thereby perpetuating inequality both within and between States." ${ }^{\prime 35}$

Most libraries attempt to combat the digital divide by providing Internet access within their libraries. However, this is limited in scope and does not adequately address the need for access beyond library walls. The New York Public libraries recently took an innovative approach and launched a "Library HotSpot" program that lends

\footnotetext{
${ }^{33}$ García Landa, "Academic Language Barriers and Language Freedom," 72.

${ }^{34}$ Winter, "Is Internet Access a Human Right?"

${ }^{35}$ La Rue, "Report of the Special Rapporteur on the Promotion and Protection of the Right to Freedom of Opinion and Expression, Frank La Rue," 17.
} 
wireless modems for home use. ${ }^{36}$ Libraries located in communities that have access to broadband, but where patrons lack financial resources, may be able to offer similar lending services.

Librarians can advocate for Internet access not only at a local level, but also at a national, or even international level. Many countries have recognized Internet access as a basic human right including Estonia, France, Costa Rica, and Finland. ${ }^{37}$ Librarians around the globe should be at the forefront of advocating for Internet access for their patrons because accessing much of today's information requires it.

We wish to end by acknowledging an internal tension-that we bring unearned privilege to solving the problems we discuss in this article. As we seek to dismantle different systems of unearned privilege, we recognize we are participants in the system and benefit from it. As Philip Altbach wrote in his highly cited article, Globalisation and the University: Myths and Realities in an Unequal World, "Recognising inequality is the first step. The second is to create a world that ameliorates those inequalities." ${ }^{38}$ Though librarians in the global north certainly have a responsibility to help shift information to be free for all users, creating that reality is a shared opportunity.

\section{Acknowledgements}

A special thanks to Pep Torn, Library Director at European University Institute, and Hui Zhang, Digital Applications Librarian at Oregon State University, for translating our abstract into Spanish and Chinese.

\section{References}

Alperin, Juan Pablo, Gustavo Fischman, and John Willinsky. "Open access and scholarly publishing in Latin America: ten flavours and a few reflections / Acesso livre e publicação acadêmica na América Latina: dez sabores e algumas reflexões." Liinc em Revista 4, no. 2 (2008). http://revista.ibict.br/liinc/index.php/liinc/article/view/269.

Altbach, Philip G. "Globalisation and the University: Myths and Realities in an Unequal World." Tertiary Education \& Management 10, no. 1 (2004): 3-25.

Ammon, Ulrich. "Global English and the Non-Native Speaker: Overcoming Disadvantage." In Language in the Twenty-First Century : Selected Papers of the Millenial Conferences of the Center for Research and Documentation on World Language Problems, Vol. 1. Studies in World Language Problems. University of Hartford and Yale University: J. Benjamins Pub. Co., 2003.

Baussano, Iacopo, Patrick Brzoska, Ugo Fedeli, Claudia Larouche, Oliver Razum, and Isaac CH Fung. "Does Language Matter? A Case Study of Epidemiological and Public Health Journals, Databases and Professional Education in French, German and Italian." Emerging Themes in Epidemiology 5, no. 1 (September 30, 2008): 16. doi:10.1186/1742-7622-5-16.

"Committee on Freedom of Access to Information and Freedom of Expression (FAIFE)." IFLA, January 29, 2015. http://www. ifla.org/about-faifeMay 7, 2015.

\footnotetext{
36 "Library HotSpot."

${ }^{37}$ La Rue, "Report of the Special Rapporteur on the Promotion and Protection of the Right to Freedom of Opinion and Expression, Frank La Rue."

${ }^{38}$ Altbach, "Globalisation and the University: Myths and Realities in an Unequal World," 24.
} 
Cox, John. "As I See It! -- Why Is Private Equity Interested In Publishing?" Against the Grain 19, no. 6 (November 4, 2013). http://docs.lib.purdue.edu/atg/vol19/iss6/31.

Dahn, Bernice, Vera Mussah, and Cameron Nutt. "Yes, We Were Warned about Ebola." The New York Times. April 7, 2015, sec. Opinion. http://www.nytimes.com/2015/04/08/opinion/yes-we-were-warned-aboutebola.html?_r=0.

Descarries, Francine. "Language Is Not Neutral: The Construction of Knowledge in the Social Sciences and Humanities." Signs: Journal of Women in Culture \& Society 39, no. 3 (Spring 2014): 564-69.

"Ethnologue: Languages of the World." Ethnologue. Accessed May 13, 2015. http://www. ethnologue.com.

Fischman, Gustavo E., Juan Pablo Alperin, and John Willinsky. "Visibility and Quality in Spanish-Language Latin American Scholarly Publishing. "Information Technologies \& International Development 6, no. 4 (December 9, 2010): pp. 1-21.

Fung, Isaac. "Open Access for the Non-English Speaking World: Overcoming the Language Barrier." Emerging Themes in Epidemiology 5, no. 1 (January 4, 2008).

García Landa, Laura Gabriela. "Academic Language Barriers and Language Freedom." Current Issues in Language Planning 7, no. 1 (December 22, 2008): 61-81.

"Global Publishing Leaders 2014: Reed Elsevier." PublishersWeekly.com. Accessed April 28, 2015. http://www.publishersweek/y.com/pw/by-topic/industry-news/publisher-news/article/63099-global-publishing-leaders-2014-reed-elsevier.html.

"Global Publishing Leaders 2014: Thomson Reuters." PublishersWeekly.com. Accessed April 28, 2015. http://www.publishersweek/y.com/pw/by-topic/industry-news/publisher-news/article/63103-global-publishing-leaders-2014-thomson-reuters.html.

"IFLA Code of Ethics for Librarians and Other Information Workers (Full Version). "IFLA, August 2012. http://www. ifla.org/news/ifla-code-of-ethics-for-librarians-and-other-information-workers-full-version.

"Internet Seen as Positive Influence on Education but Negative on Morality in Emerging and Developing Nations." Pew Research Center, March 2015. http://www.pewglobal.org/files/2015/03/Pew-Research-Center-Technology-Report-FINAL-March-19-20151.pdf.

Laakso, Mikael, and Bo-Christer Björk. "Anatomy of Open Access Publishing: A Study of Longitudinal Deve/opment and Internal Structure. "BMC Medicine 10, no. 1 (October 22, 2012): 124. doi:10.1186/17417015-10-124.

La Rue, Frank. "Report of the Special Rapporteur on the Promotion and Protection of the Right to Freedom of Opinion and Expression, Frank La Rue," May 16, 2011. http://www2.ohchr.org/english/bodies/hrcouncil/docs/17session/A.HRC.17.27_en.pdf.

Lawson, Stuart, Kevin Sanders, and Lauren Smith. "Commodification of the Information Profession: A Critique of Higher Education Under Neoliberalism. "Journal of Librarianship and Scholarly Communication 3, no. 1 (March 10, 2015). doi:http://dx.doi.org/10.7710/2162-3309.1182.

"Libraries: How They Stack up." OCLC, 2003. https://www.oclc.org/content/dam/oclc/reports/librariesstackup.pdf.

"Library HotSpot." New York Public Library. Accessed July 27, 2015. http://hotspot.nypl.org.

"Members of the FAIFE Committee." IFLA, April 30, 2015. http://www. ifla.org/faife/members.

Noack, Rick, and Lazaro Gamio. "The World's Languages, in 7 Maps and Charts." The Washington Post. April 23, 2015, sec. WorldViews. http://www.washingtonpost.com/blogs/worldviews/wp/2015/04/23/theworlds-languages-in-7-maps-and-charts/.

"Sustaining Human Progress: Reducing Vulnerabilities and Building Resilience." Human Development Report. New York, NY: United Nations Development Program, 2014. http://hdr.undp.org/sites/default/files/hdr14-report-en-1.pdf.

Tardy, C. "The Role of English in Scientific Communication: Lingua Franca or Tyrannosaurus Rex?" Journal of English for Academic Purposes 3, no. 3 (July 2004): 247-69. doi:10.1016/j.jeap.2003.10.001. 
"The World's 56 Largest Book Publishers, 2014." PublishersWeekly.com. Accessed April 28, 2015. http://www.publishersweek/y.com/pw/by-topic/industry-news/financial-reporting/article/63004-theworld-s-56-largest-book-publishers-2014.html.

"UNESCO Institute for Statistics Data Centre." United Nations Educational, Scientific, and Cultural Organization, n.d. http://Www. uis.unesco.org/DataCentre/Pages/BrowseEducation.aspx.

"United Nations Declaration of Human Rights." United Nations, December 10, 1948. http://www. un.org/en/documents/udhr/index.shtm/\#a19.

Van Leeuwen, Thed N, Henk F Moed, Robert JW Tijssen, Martijn S Visser, and Anthony FJ Van Raan. "Language Biases in the Coverage of the Science Citation Index and Its Consequences for International Comparisons of National Research Performance." Scientometrics 51, no. 1 (2001): 335-46.

Winter, Jenifer Sunrise. "Is Internet Access a Human Right?" The Global Studies Journal 5, no. 3 (2013): 35 48.

"World Population Prospects: The 2012 Revision. "United Nations, Department of Economic and Social Affairs. Accessed May 12, 2015. http://esa.un.org/unpd/wpp/unpp/panel_population.htm.

Xiaohua Zhu. "The National Site Licensing of Electronic Resources: An Institutional Perspective." 图书信息学 刊/\#/圖書資訊學刊 [[TUSHU ZIXUN XUEKAN]] 9, no. 1 (n.d.): 51-76. 